\title{
MEDIA FOR THE ISOLATION AND DIFFERENTIATION OF PATHOGENIC ESCH. COLI (SEROTYPES O 111 AND O 55)
}

\author{
BY \\ F. RAPPAPORT AND E. HENIG \\ From the Microbiological Laboratories, the Beilinson Hospital, Petah Tiqua, and the Municipal Hadassa \\ Hospital, Tel-Aviv, Israel
}

(RECEIVED FOR PUBLICATION MAY 3, 1952)

The connexion between Escherichia coli and intestinal disease was observed for the first time by Adam (1923), who described the types of Bact. coli found in toxic intestinal diseases of infants. Later he named these bacteria "dyspepsiecoli" (Adam, 1927) and divided them into six groups, A1-A6, according to their fermentative properties in relation to various sugars and alcohols. According to Adam, the two predominant types in clinical cases were Al and A4, and he designated them dyspepsiecoli sensu strictori. Goldschmidt (1933) typed these strains and found that they formed a separate serological group.

Since then many workers (Bray, 1945; Giles and Sangster, 1948 ; Giles, Sangster, and Smith, 1949 ; Taylor, Powell, and Wright, 1949 ; Rogers, Koegler, and Gerrard, 1949 ; Drimmer-Herrnheiser, and Olitzki, 1951 ; Dupont, 1951 ; Braun, 1951) have found in diarrhoea and vomiting (gastro-enteritis) in infants a predominant bacterial flora, Escherichia coli, which was named by Bray (1945) Bact. coli neapolitanum, by Giles and Sangster (1948) Bact. coli type alpha and beta, by Taylor et al. (1949) D 433, and by Rogers et al. (1949) B.G.T. These strains of Esch. coli behave as a distinct serological type. The classification was made by Kauffmann and Dupont (1950), who found that these bacteria belonged to the groups O $111:$ B4, O $111:$ B4 : H2, O $111:$ B4 : H12, and O $55:$ B5 : H6.

The growth properties and morphology of these strains are identical with those of other strains of Esch. coli, and till now the only means of differentiation has been based on their serological specificity. Even Adam and Aust (1950), who paid particular attention to their biochemical properties, stressed that "... as the fermentative properties of these bacteria are unstable and given to fluctuations, it is safer to identify these strains of $B$. coli by means of specific agglutinating sera." A slide agglutination method for identification was also introduced by Bray and Beavan (1948).

We became interested in the possibility of a rapid biochemical differentiation of these pathogenic strains of Esch. coli, as it has always been necessary to test serologically all of the colonies diagnosed on McConkey medium as Esch. coli in order to be sure that no possible pathogenic colony had been omitted. This procedure, laborious and time-consuming, is impractical for diagnostic purposes.

\section{Method}

Some indications of a possible biochemical differentiation were found in previous investigations when Silberstein, Rappaport, and Kolmer (1932) encountered strains of Esch. coli that did not ferment sorbitol. Since the serotypes $O 111$ and $O 55$ of Esch. coli were found to ferment sorbitol slowly or not at all, we tried to include sorbitol in solid media of the type of McConkey. In our final medium the lactose of the McConkey medium was replaced by $d$-sorbitol according to the following formula:

\begin{tabular}{|c|c|c|c|c|c|}
\hline Bacto peptone . & . & . & . & . & $17 \cdot 0 \mathrm{~g}$ \\
\hline Proteose peptone & . & . & . & $\therefore$ & $3 \cdot 0$ \\
\hline$d$-Sorbitol $\quad \cdots$ & . & . & . & . & $10 \cdot 0$ \\
\hline Bacto bile salts No. 3 & . & . & . & . & 1.5 \\
\hline Sodium chloride & . & . & .. & $\ldots$ & $5 \cdot 0$ \\
\hline Bacto agạ $\quad$. & . & . & . & . & $13 \cdot 5$ \\
\hline Neutral red & & . & $\cdots$ & . & $0.3,, *$ \\
\hline Crystal violet $(0.1 \%$ so & lution) & & . & . & 1.0 \\
\hline Distilled water ... & . & . & $\ldots$ & . & $1,000 \mathrm{ml}$ \\
\hline
\end{tabular}

This medium was sterilized in an autoclave for 20 minutes at $15 \mathrm{lb}$./sq. in., poured into petri dishes, and left to solidify. A little faecal suspension in saline was streaked on the surface of the plate which was incubated for 18 to 24 hours at $37^{\circ} \mathrm{C}$. Sorbitolfermenters - that is, most of the non-pathogenic strains of Esch. coli-formed red colonies, but patho-

* This high concentration of neutral red (accidentally used in the 


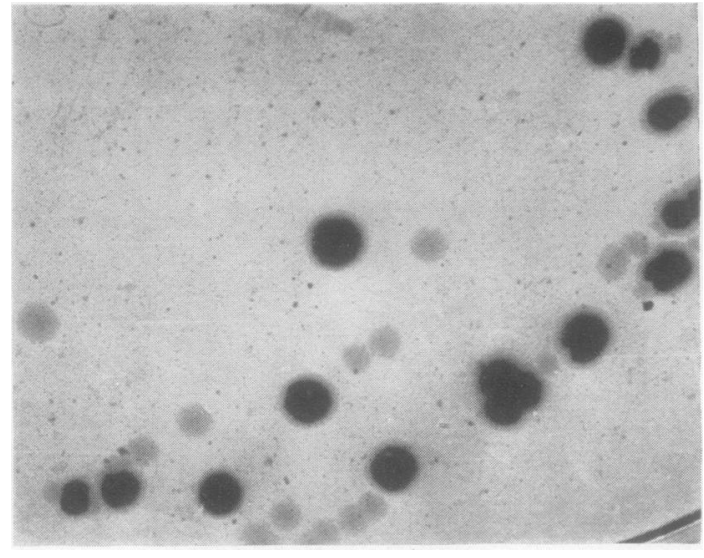

Fig. 1

genic Esch. coli grew in colourless colonies similar to those of non-lactose fermenters on McConkey medium (Fig. 1). As some strains of B. proteus and some Shigellae also grew on sorbitol-agar as colourless colonies. the final differentiation of the pathogenic Esch. coli was made on iron-sorbitol-agar slants of the type of Kligler's iron agar, the sugar again being replaced by sorbitol.

lron-sorbitol-agar slants were prepared as follows:

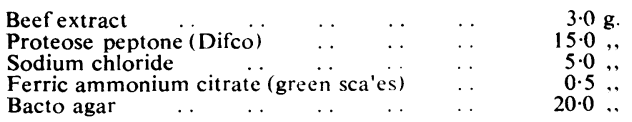

The mixture was dissolved in $1.000 \mathrm{ml}$. distilled water and the $p \mathrm{H}$ adjusted to 7.6 with $\mathrm{NaOH}$. Finally it was distributed in $100-\mathrm{ml}$. quantities into bottles and sterilized in an autoclave.

A mixture was prepared by grinding in a mortar the following:

$\begin{array}{llllll}\text { Phenol red (powder) } & \ldots & \ldots & \ldots & \ldots & 0.15 \mathrm{~g} . \\ d \text {-Sorbitol } & \ldots & \ldots & \ldots & \ldots & 10.0 ., \\ \text { Sodium thiosulphate } & \ldots & \ldots & \ldots & \ldots & 2.5,\end{array}$

Of this mixture, $0.25 \mathrm{~g}$. was added to each $100 \mathrm{ml}$. of melted medium, stirred till dissolved, then distributed into small tubes, autoclaved, and left to solidify in a slanted position.

After 18 to 24 hours of incubation at $37^{\circ} \mathrm{C}$. stab inoculation of colourless colonies into this medium gave a slight anaerobic fermentation without producing gas, while normal red colonies of Esch. coli grew with the formation of acid and gas. $B$. proteus, which also may form colourless colonies, blackens sorbitol-iron-agar slants due to the production of $\mathrm{H}_{2} \mathrm{~S}$.
The colourless colonies of Esch. coli gave distinct agglutination with $\mathrm{O} 111: \mathrm{B} 4$ and $\mathrm{O} 55: \mathrm{B} 5$ sera, while no agglutination was observed in the case of red colonies from sorbitol-agar. As not all colourless colonies are Esch. coli, the serological types should be finally established by agglutination with specific sera and by such biochemical reactions as indol- and urease-production and behaviour on Kligler's iron agar and sorbitol-ironagar. It is possible that new and hitherto undescribed types of Esch. coli may ferment sorbitol slowly or not at all. It remains to be seen whether such types, if they arise, are associated with infantile gastro-enteritis. After subcultures on laboratory media some strains of Esch. coli types O 111 and O 55 may develop the ability to ferment sorbitol, but this has never been found in the case of freshly isolated strains.

Finally it should be mentioned that Kauffmann and Dupont (1950) and Braun (1951) observed that sorbose was not fermented by the pathogenic strains of Esch. coli. We are now investigating the effects of the inclusion of sorbose as a differentiating sugar in solid media.

\section{Summary}

Strains of Esch. coli of the serotype O 111 and O 55 can be biochemically differentiated on sor bitol-agar medium and in sorbitol-iron-agar slants, due to their ability to ferment sorbitol only slowly or not at all. It is suggested that some of the sorbitol-non-fermenting strains of Esch. coli may belong to new and as yet undefined serological types.

We wish to thank Mrs. Iza Hirschberg-Glueckman and Mr. Dov Mizrahi for their help in this investigation.

\section{REFERFNCES}

Adam. A. (1923). Jb. Kinderheilk., 101, 295 (1927). Ibid , 116, 8

and Aust, B. (1950). Mschr. Kinderheilk., 98, 356

Braun, O. H. (1951). Z. Hyg. Infekt Kr., 132, 548

Bray, J. (1945). J. Path. Bact., 57, 239.

Bray, Jand Beavan, T. E. D (1948) Ibid. 60, 395

Trimmer Berta med. orient. Tel-Aviv, 10, 219.

Dupont, A. (1951). Nord. Med., 46, 1194

Giles, C., and Sangster. G. (1948). J. Hyg., L.ond., 46, 1

- Arch. Dis. Childh., 24, 45

Goldschmidt, R. (1933). Jo. Kinderheilk., 139, 318.

Kauffmann, $\vec{F}$. Acta path. microbiol. scand

27, 552 .
Rogers, K. B., Koeg'er, S. J., and Gerrard, J. (1949). Brit. med. J., 2,1501 .

Silberstein, F., Rappaport, F., and Kolmer, E. (1932). Zbl. Bakt I Abt. Orig., 124, 32

Taylor, J., Poweli, B. W.., and Wright. J. (1949). Brit. med.J.. 2, 117 